TAPROBANICA, ISSN 1800-427X. June, 2014. Vol. 06, No. 01: pp. 60-62, 4 pls.

(C) Research Center for Climate Change, University of Indonesia, Depok, Indonesia

\& Taprobanica Private Limited, Homagama, Sri Lanka

http://www.sljol.info/index.php/tapro

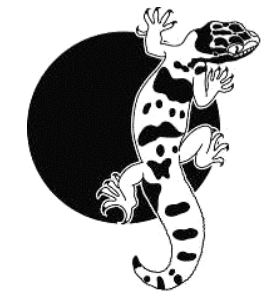

\section{Morning territorial calls of male oriental magpie robin (Copsychus saularis)}

Oriental magpie robin, Copsychus saularis (Linnaeus, 1758) a resident breeder in tropical Southern Asia including India, Bangladesh, Pakistan, Sri Lanka, east Indonesia, south China and Phillippines (Siddique, 2008; Ali, 2003), prefers cultivated areas, woodlands and areas close to human settlement. It is mainly insectivore and its activities are influenced by surrounding environment (Siddique, 2008). Rajasthan is the largest state of India and distribution of this species is restricted to southeastern part of the state (Siddique, 2008). The study was conducted in Sitamata Wildlife Sanctuary $\left(24^{\circ} 04^{\prime}-24^{\circ} 23^{\prime} \mathrm{N}, 7^{\circ} 25^{\prime}-74^{\circ} 40^{\prime} \mathrm{E}\right)$, located in southern Rajasthan, India, and covers an area about $423 \mathrm{~km}^{2}$.

Ten males of this species were studied in July, 2012 and which were nested in thickets of Bamboos (Dendrocalamus strictus). During the morning session, birds started singing from about 04:30-05:45 $\mathrm{h}$ in and around their nests. Acoustic data were recorded under natural condition using Sony Digital camera (DCRSR45E E34). The recorded sound was separated by Total Video Converter software and converted into wave audio file. The sounds were analyzed and spectrograms were obtained with the help of sound analysis software (Raven Pro 1.4). Parameters like minimum frequency, maximum frequency, duration and interval between phrases were used to define the physical characteristics of the sound. Description of the sounds was followed Bhatt et al., (2000) and Kumar \& Bhatt (2001).

A total of 304 calls recorded during the study period and their characteristics are presented in the table 1 . The whole morning calls were divided into four time segments (04:30-04:40 h; 04:40-05:07 h; 05:07-05:25 h; 05:25-05:45 h) according to structure and length of sound phrases. During the early time period of activity or between 04:30 and 04:40 h, oriental magpie robin (OMR) did not found any response from other directions and phrase duration was found lowest $(3.20 \pm 0.6 \mathrm{sec}$.) than rest time segments. As the time was exhausted, the length of phrases became long (Table 2 and Fig. 1) and complex. Fluctuation was also noted in the frequency range (Table 2). According to Kumar \& Bhatt (2001), the rate of call delivery varied according to the situation. Usually, birds use song repertoires to communicate with their close neighbors, to announce and assess their strength or willingness to defend the territory, or to challenge neighbors on a daily basis throughout the breeding season (i.e. social dynamic hypothesis) (Sethi et al., 2011).

Table 1: Parameters of morning territorial calls of OMR from 04:30-05:45 h $(n=304)$.

\begin{tabular}{lc}
\hline \multicolumn{1}{c}{ Variable } & Values \\
\hline Phrase duration (sec.) & $5.14 \pm 2.2$ \\
Minimum frequency $(\mathrm{kHz})$ & $2.02 \pm 0.3$ \\
Maximum frequency $(\mathrm{kHz})$ & $6.93 \pm 0.4$ \\
Interval between phrases $(\mathrm{sec})$. & $5.68 \pm 4.3$ \\
\hline
\end{tabular}

Table 2: Parameters of morning territorial calls of OMR during different time period (mean $\pm \mathrm{SD}$ ), (PD, phrase duration (sec.); MinF, minimum frequency $(\mathrm{kHz})$; MaxF, maximum frequency $(\mathrm{kHz})$; IBP, Interval between phrases (sec.))

\begin{tabular}{ccccc}
\hline $\begin{array}{c}\text { Time } \\
\text { period }\end{array}$ & $\boldsymbol{n}$ & $\begin{array}{c}\text { Types of } \\
\text { phrases }\end{array}$ & Variable & Values \\
\hline & & & $\mathrm{PD}$ & $3.20 \pm 0.6$ \\
$04: 30-$ & 62 & 5 & $\mathrm{MinF}$ & $1.55 \pm 0.2$ \\
$04: 40 \mathrm{~h}$ & & & $\mathrm{MaxF}$ & $6.51 \pm 0.2$ \\
& & & $\mathrm{IBP}$ & $6.20 \pm 5.4$ \\
& & & $\mathrm{PD}$ & $4.94 \pm 2.0$ \\
$04: 40-$ & \multirow{2}{*}{70} & 8 & $\mathrm{MinF}$ & $2.15 \pm 0.1$ \\
$05: 07 \mathrm{~h}$ & & & $\mathrm{MaxF}$ & $6.96 \pm 0.4$ \\
& & & $\mathrm{IBP}$ & $5.78 \pm 3.5$ \\
& & & $\mathrm{PD}$ & $5.88 \pm 1.7$ \\
$05: 07-$ & \multirow{2}{*}{52} & 5 & $\mathrm{MinF}$ & $2.14 \pm 0.2$ \\
$05: 25 \mathrm{~h}$ & & & $\mathrm{MaxF}$ & $7.07 \pm 0.2$ \\
& & & $\mathrm{IBP}$ & $5.64 \pm 4.1$ \\
& & & $\mathrm{PD}$ & $7.68 \pm 3.1$ \\
$05: 25-$ & \multirow{2}{*}{80} & 5 & $\mathrm{MinF}$ & $2.18 \pm 0.3$ \\
$05: 45 \mathrm{~h}$ & & & $\mathrm{MaxF}$ & $7.15 \pm 0.4$ \\
& & & $\mathrm{IBP}$ & $5.12 \pm 4.0$ \\
\hline
\end{tabular}




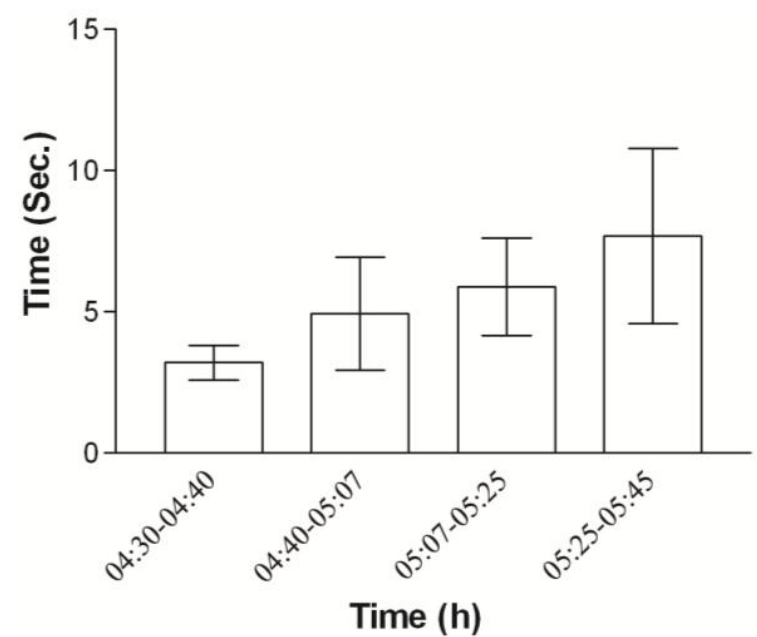

Figure 1: Phrase duration (Sec.) of OMR during morning territorial calls in different time segments.

During the study period, it was found that OMR initiated its singing activity earlier than other bird species in the study area. During initial stage, birds were found among clumps of Bamboos when they did not find any response from other sides, but when they started to get responses from other conspecific birds, they change their position and reached at the top of the clumps. With changing its position, songs also became complex and long (Fig. 2 to 5) to possibly defend their territories. They showed more strongly predominance with the progress of time. Singing activity of individual males can be related to the number of males singing in the same area (Lampe \& Espmark 1987). Two main strategies may have been adopted by OMR for defending a large breeding territory: (i) the bird uses lower frequencies, rapid pulse and complex structure of sound, and (ii) it delivers its song from higher posts like the top, naked branches which may reduce the attenuation and degradation of sound and spread the signal over a wider area (Bhatt et al., 2000). Complex and varied songs have been also observed in many other avian species (Catchpole, 1976; Eens et al., 1991; Bell et al., 2004; Kloubec \& Capek, 2005; Wickler et al., 2006).

Many authors also studied morning territorial calls of birds which are found similar to the present study (Mayaud, 1930; Dementiev \& Gladkov 1954). Marsh warbler sings most in the morning and its singing activity found related to the twilight periods (Kloubec \& Capek 2000). Changes of light intensity around sunrise and sunset appear to be the most important proximate stimuli controlling the onset and cessation of the diurnal rhythm, although less significant changes in temperature and humidity also occur at this time. Song concentrated at certain times, particularly at dawn, is characteristic of many birds (Kloubec \& Capek 2005).

During the study period, 23 types of phrases were identified with variability in their notes. Different elements are often used to determine the degree of song difference in each population group and are important for communication between males and their neighbors in each population area, particularly in territorial defense (Beme, 1994; Bigot et al., 1994; Dunmak \& Sitasuwan, 2007). In the present observation, beginning elements of calls (Figure 1 and 2) are found similar with very little variables. Dunmak \& Sitasuwan (2007) identified that beginning of each strophe can be considered as species recognition for the OMR, and there are high similarities among populations. These core elements appeared as a group of bands whose frequency did not vary. Bhattacharya et al., (2007) also showed that rapid matching dominates at the beginning of the singing when songsters set up territories, i.e. mainly during highly agonistic interactions. In contrast, delayed matching can be found particularly when territories are established.

\section{Acknowledgments}

I duly acknowledge the Department of Forest, Government of Rajasthan (India) for permit and support us for the study. I also thank Satish Kumar Sharma, Assistant Conservator of Forests, Department of Forests, Rajasthan, for his valuable comments on the manuscript.

\section{Literature Cited}

Ali, S., 2003. The book of Indian birds. Oxford University Press, Oxford, UK: 466.

Bell, B. D., M. Borowiec, J. Lontkowski and S. Pledger, 2004. Short records of Marsh Warbler (Acrocephalus palustris) song provide indices that correlate with nesting success. Journal of Ornithology, 145: 8-15.

Beme, I. R., 1994. Formation of acoustic repertoire in the Turdidae. Journal of Ornithology, 135: 314.

Bhatt, D., A. Kumar, Y. Singh and R. B. Payne, 2000. Territorial songs and calls of the oriental 
magpie robin Copsychus saularis. Current Science, 78: 722-728.

Bhattacharya, H., J. Cirillo, B. R. Subba and D. Todt, 2007. Song performance rules in the Oriental Magpie Robin (Copsychus salauris). Our Nature, 5: 1-13.

Bigot, E., M. Hausberger and P. Clergeau, 1994. Dialects and social organization within roosts in starling. Journal of Ornithology, 135: 316.

Catchpole, C. K., 1976. Temporal and sequential organization of song in the sedge among warbler (Acrocephalus schoenobaenus). Behaviour, 59: 226-246.

Champion, H. G. and S. K. Seth, 1968. A revised study of the forest types of India. Government of India, New Delhi, India.

Dementiev, G. P. and N. A. Gladkov, 1954. The birds of the USSR, vol 6. Sovetskaya Nauka, Moscow (in Russian).

Dunmak, A. and N. Sitasuwan, 2007. Song Dialect of Oriental Magpie-robin (Copsychus saularis) in Northern Thailand. The Natural History Journal of Chulalongkorn University, 7: 145-153.

Eens, M., R. Pinxten and R. F. Verheyen, 1991. Male song as a cue for mate choice in the European Starling. Behaviour, 116: 210-238.

Kloubec, B. and Capek M. (2000) Diurnal, nocturnal and seasonal patterns of singing activity in Marsh Warblers. Biologia, 55:185- 193.

Kloubec, B. and M. Capek, 2005. Seasonal and diel budget of song: a study of Savi's Warbler (Locustella luscinioides). Journal of Ornithology, 146: 206-214.

Kumar, A. and D. Bhatt, 2001. Characteristics and Significance of calls in Oriental Magpie Robin. Current Science, 80: 77-82.

Lampe, H. M. and Y. O. Espmark, 1987. Singing activity and song pattern of the redwing Turdus iliacus during the breeding season. Ornis Scand, 21: $37-45$.

Mayaud, P. N., 1930. La Locustelle luscinioide Locustella luscinioides luscinioides (Savi) dans l'ouest et le centre de la France. Alauda 2: 318327.
Sethi, V. K., D. Bhatt and A. Kumar, 2011. Song repertoire size of the Pied Bushchat Saxicola caprate. Current Science, 100: 302-204.

Siddique, Y. S., 2008. Breeding behavior of Copsychus saularis in Indian-sub-continent: a personal experience. International Journal of Zoological Research, 4: 135-137.

Wickler, W., U. Seibt and D. Schmidl, 2006. Song differences between population of seven subspecies of the African Forest Weaver Ploceus bicolor Vieillot (Aves: Passeriformes). Journal of Ornithology, 147: 87-96.

Submitted: 22 Nov. 2012, Accepted: 17 Jan. 2014 Section Editor: Varadharajan Gokula

Vijay Kumar Koli

Wildllife Reasearch Laboratory, Department of Zoology, University College of Science, Mohanlal Sukhadia University Udaipur, Rajasthan 313001, India E-mail: vijaykoli87@yahoo.in 


\section{PLATE 12}

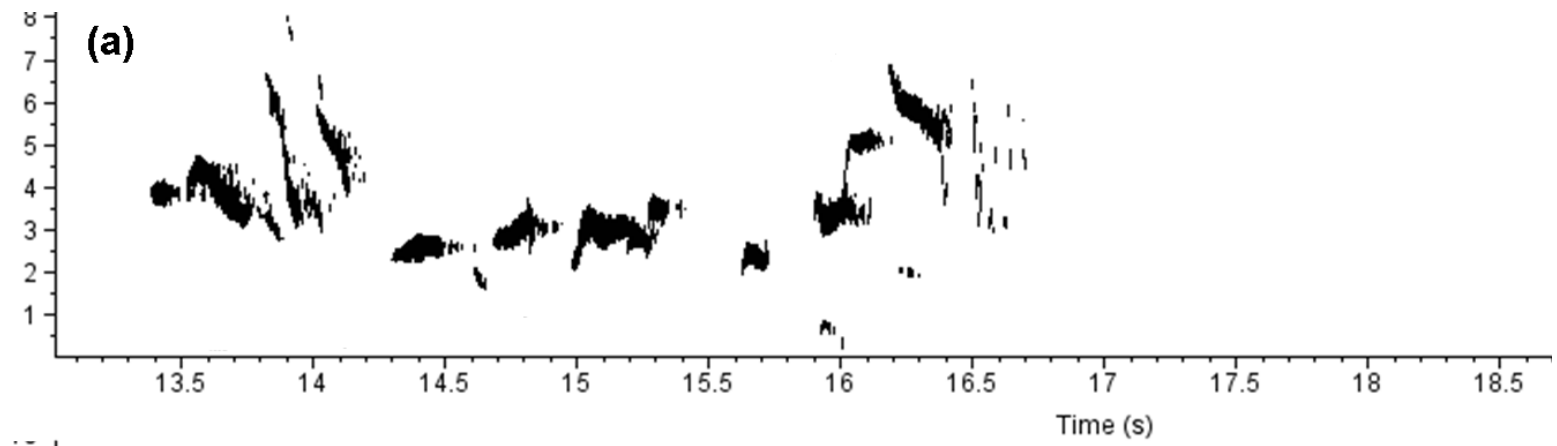

(b)

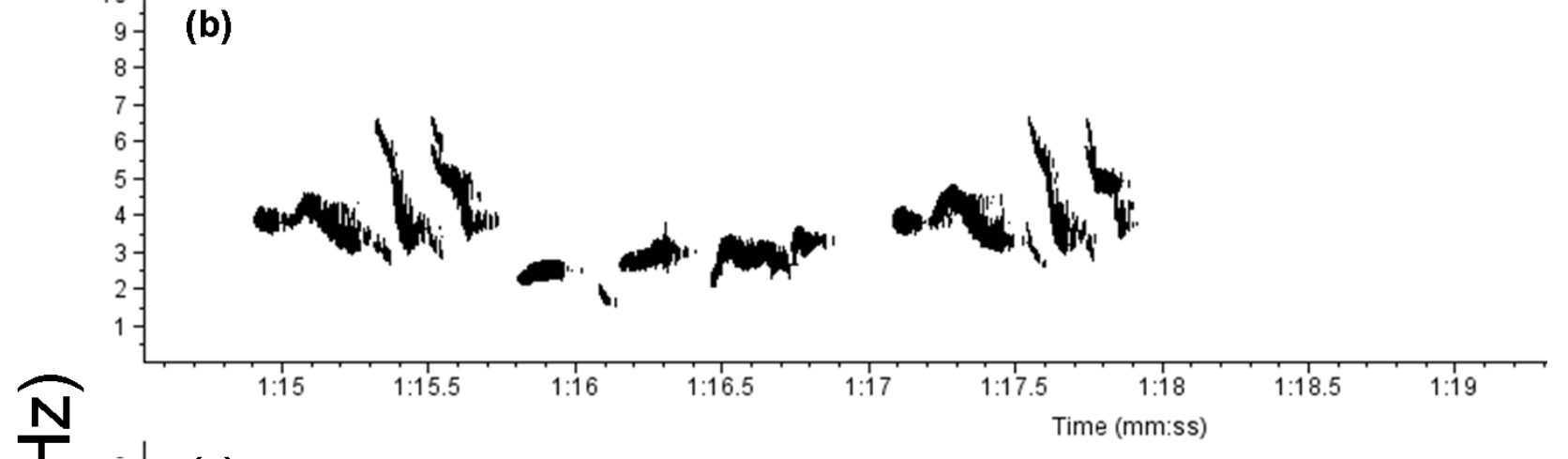

(c)

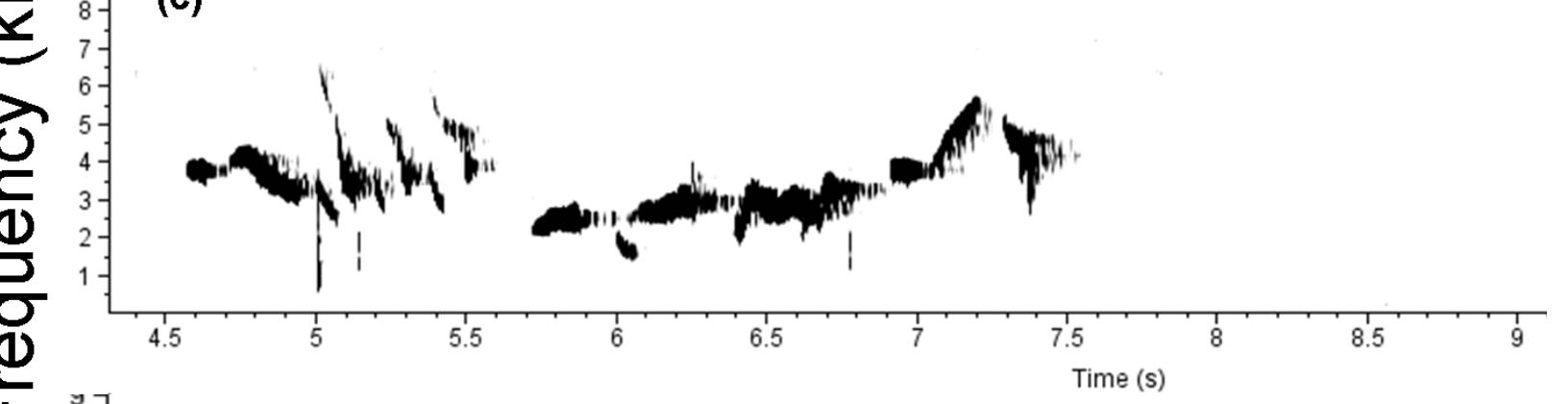

亡ั
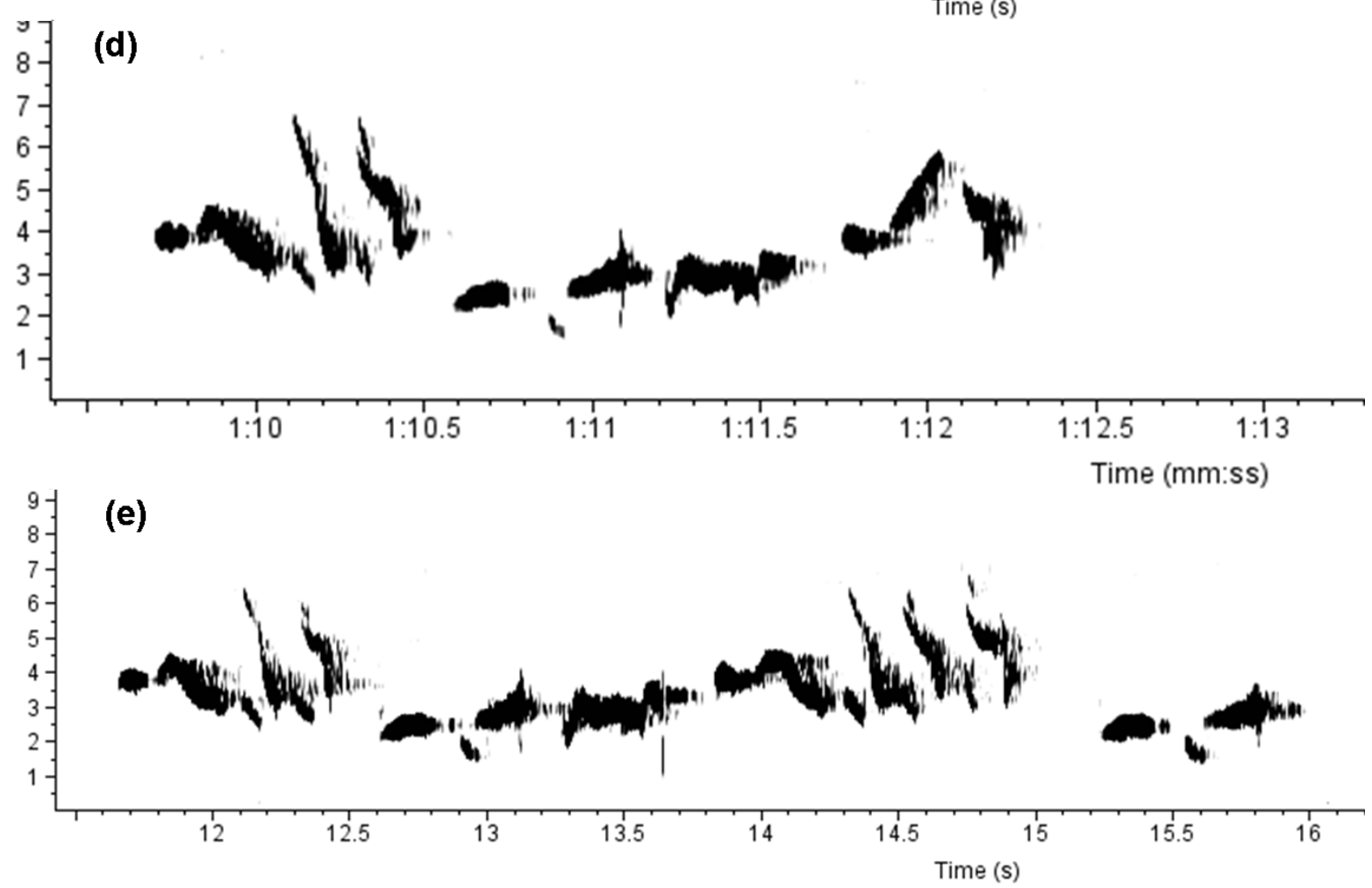

Figure 2: Sonogram (spectrogram) of complete phrases of OMR from 04:30-04:40 h. 


\section{PLATE 13}

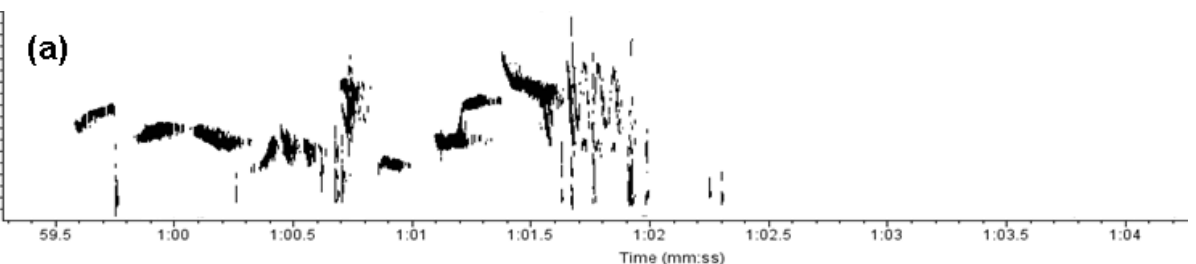

(b)

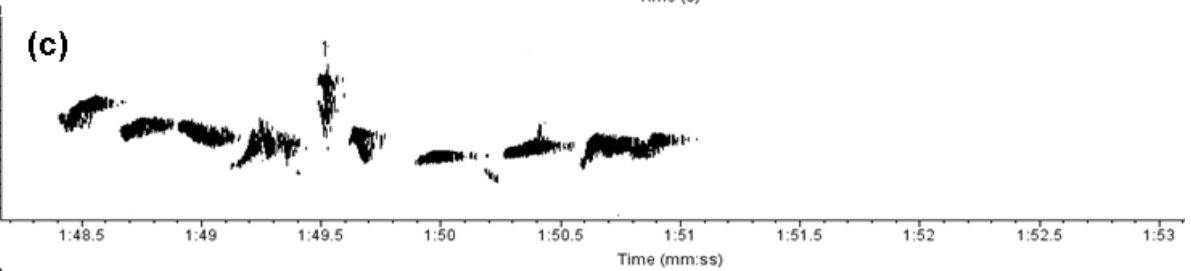

(d)
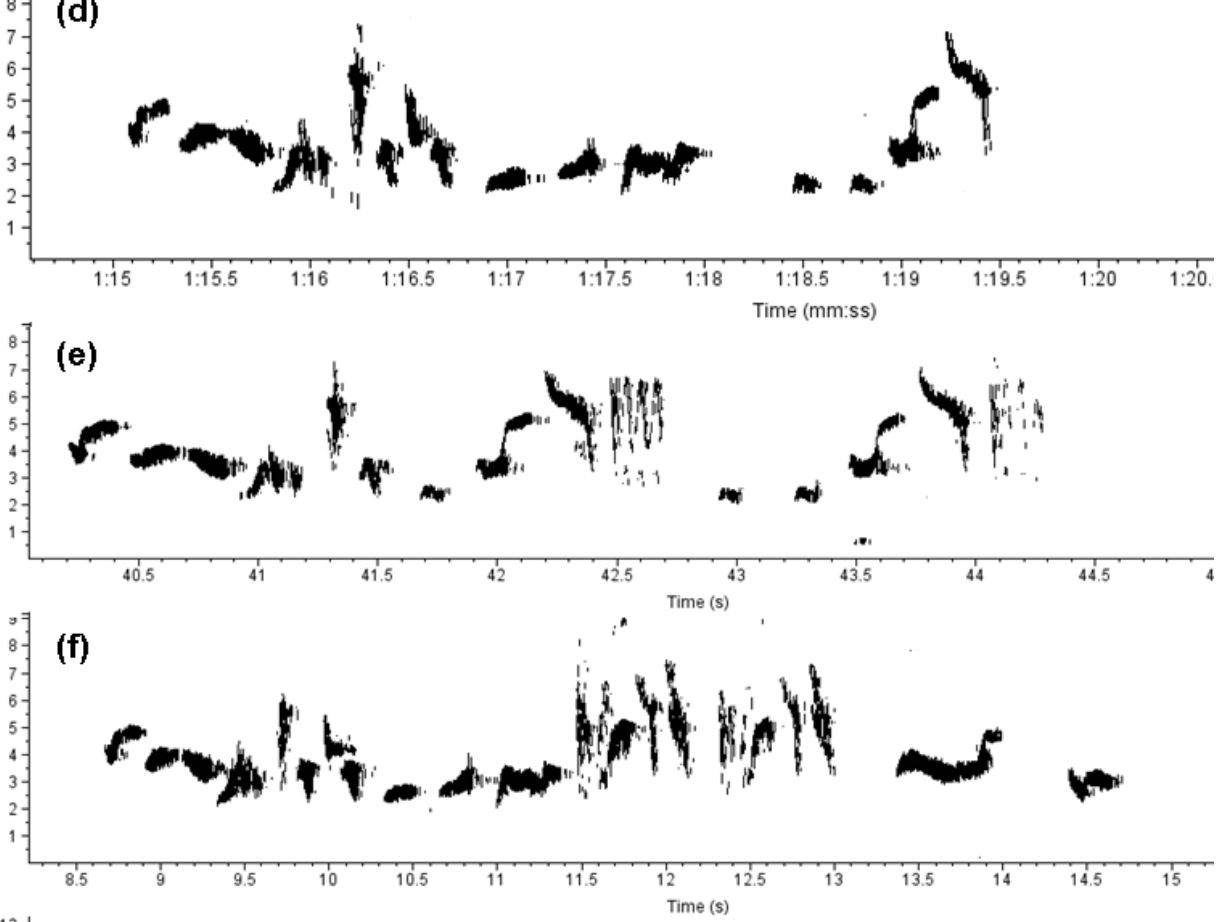

(g)
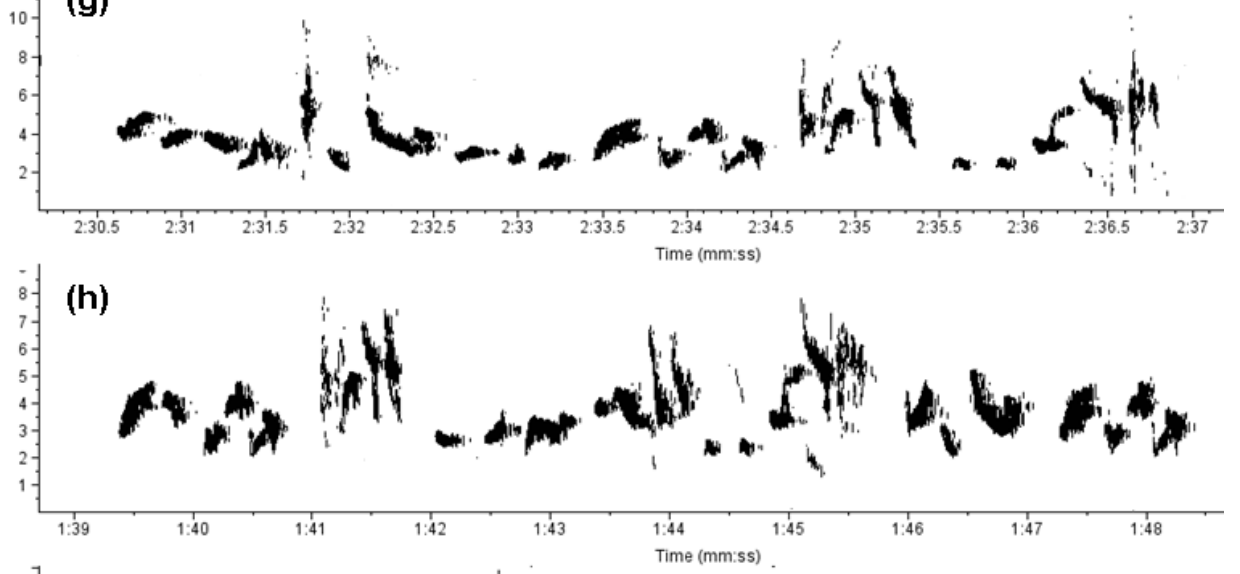

Figure 3: Sonogram (spectrogram) of complete phrase of OMR from 04:40-05:07 h. 


\section{PLATE 14}
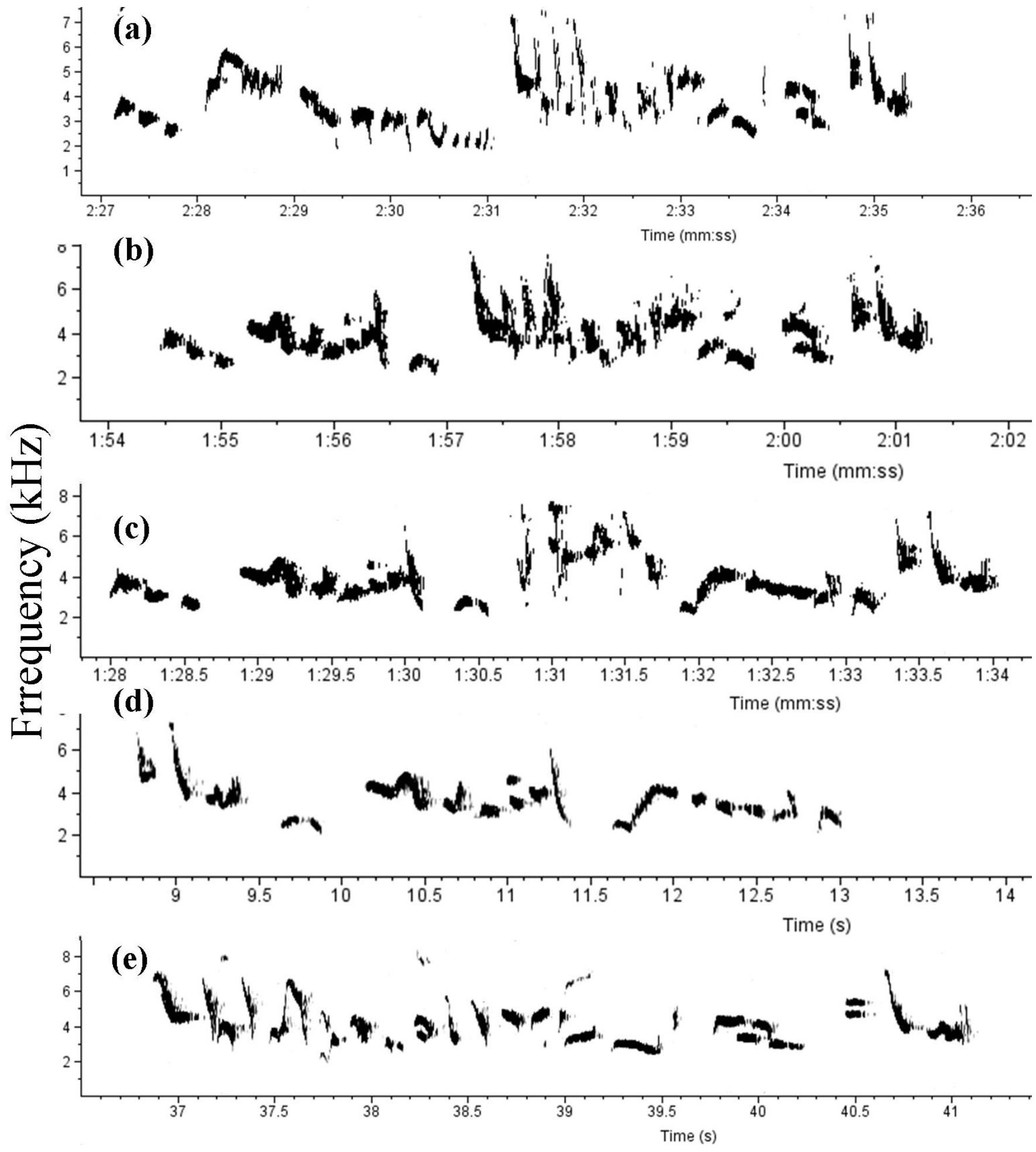

Figure 4: Sonogram (spectrogram) of complete phrases of OMR from 05:07-05:25 h. 


\section{PLATE 15}
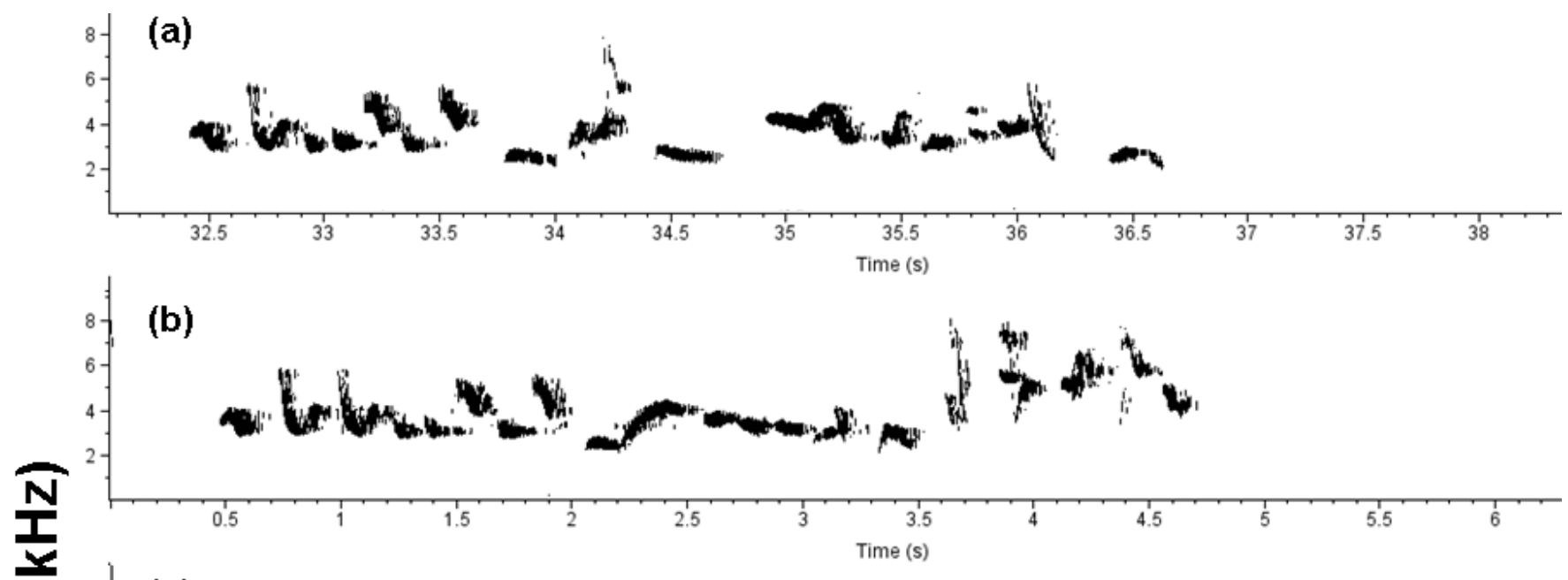

(c)

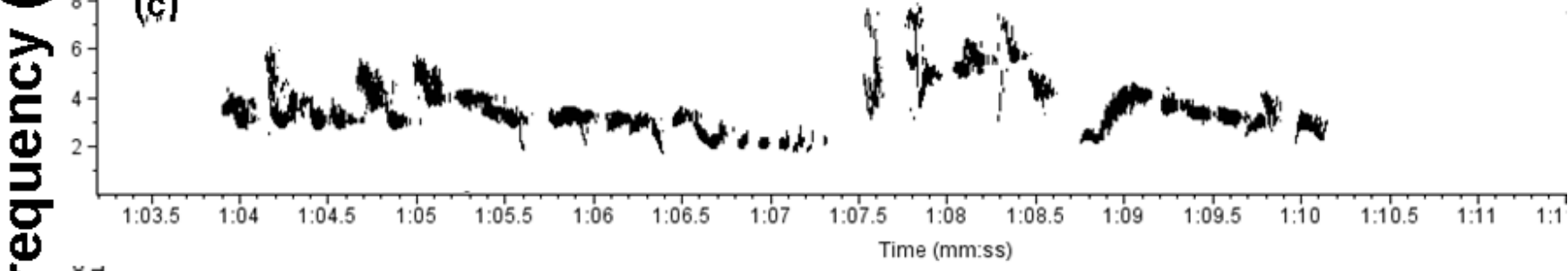

ثا
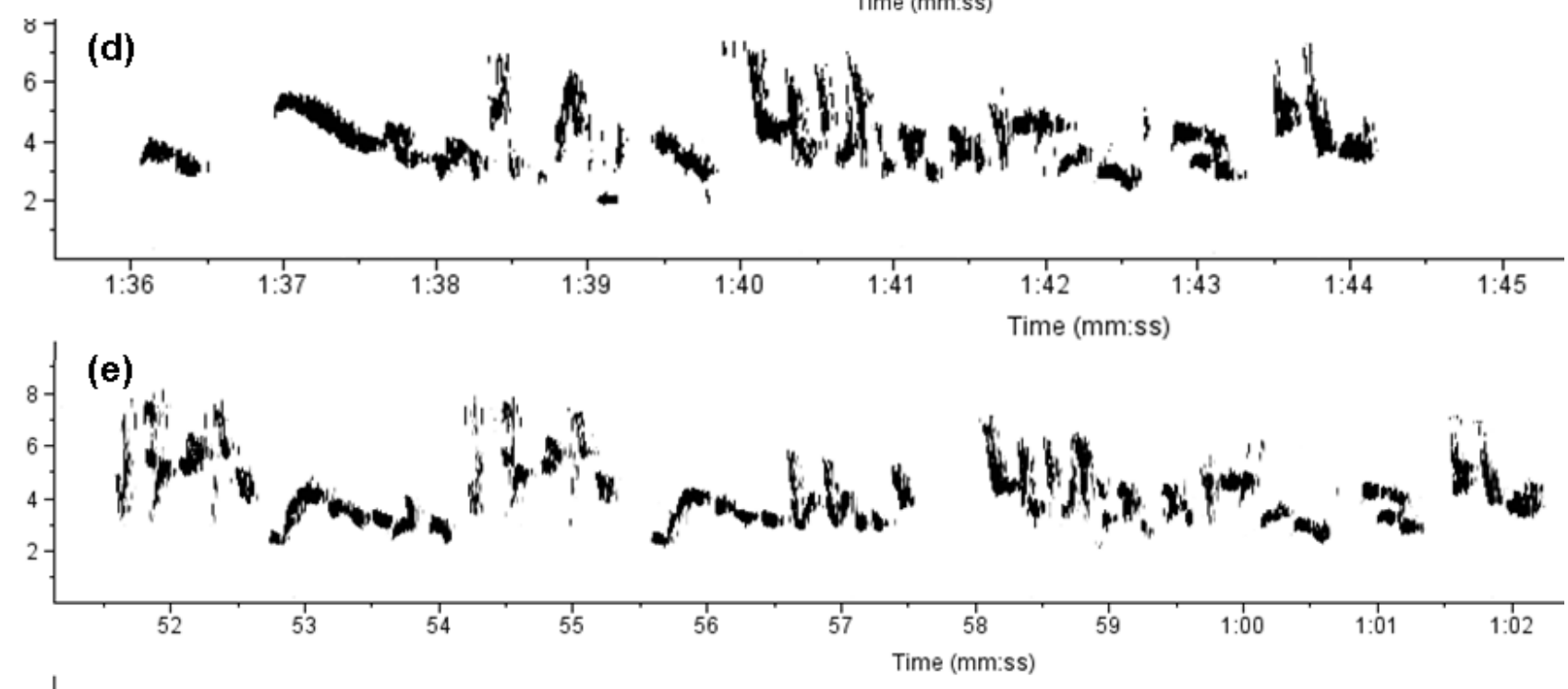

Figure 5: Sonogram (spectrogram) of complete phrases of OMR from 05:25-05:45 h. 